\title{
THE ECONOMIC GROWTH AND THE REGIONAL CHARACTERISTICS: THE CASE OF INDONESIA
}

\author{
Yesi Hendriani Supartoyo ${ }^{1}$ \\ Jen Tatuh \\ Recky H. E. Sendouw
}

\begin{abstract}
This paper analyzed the regional characteristic and the output growth. Using panel data analysis on 33 provinces in Indonesia, the result shows that the labor growth and net export positively affect the output growth. Surprisingly, the inflation and human capital were found to be insignificant on output growth.
\end{abstract}

Keyword : economic growth, panel data, regional characteristics JEL Classification: 047, C23, R11

1 Yesi is a postgraduate student on Program Studi Ilmu Perencanaan Pembangunan Wilayah dan Perdesaan (PWD), Sekolah Pasca sarjana Institut Pertanian Bogor; yesisupartoyo@mail.com. 


\section{PENDAHULUAN}

Pembangunan merupakan suatu proses menuju perubahan yang diupayakan secara terus menerus untuk meningkatkan kesejahteraan masyarakat. Salah satu indikator keberhasilan pelaksanaan pembangunan yang dapat dijadikan tolok ukur secara makro ialah pertumbuhan ekonomi yang dicerminkan dari perubahan Produk Domestik Regional Bruto (PDRB) dalam suatu wilayah. Semakin tinggi pertumbuhan ekonomi suatu wilayah menandakan semakin baik kegiatan ekonomi di peroleh dari laju pertumbuhan PDRB atas dasar harga konstan (Todaro dan Smith, 2008)

Kualitas pertumbuhan ekonomi Indonesia saat ini masih rendah. Pertumbuhan ekonomi Indonesia memang cukup tinggi, akan tetapi efek masyarakatnya terlalu rendah. Setiap 1 persen pertumbuhan ekonomi Indonesia hanya menyerap 250 ribu tenaga kerja baru (Adi, 2011)

Pertumbuhan ekonomi Indonesia yang cukup tinggi tetapi efek masyarakatnya yang terlalu rendah mengakibatkan diperlukannya analisa pengaruh karakteristik regional terhadap pertumbuhan ekonomi. Berangkat dari penelitian Sodik et al (2007) yang menyatakan bahwa keseluruhan pola kemampuan regional sebagai hasil pembawaan dari lingkungan sosial dan ekonomi sehingga menentukan pola aktivitas dalam meraih tujuan tercermin dalam karakteristik regional yang mempengaruhi pertumbuhan ekonomi yaitu berupa aspek-aspek atau kualitas regional yang terdiri dari angkatan kerja, penduduk, modal manusia (pendidikan), inflasi dan ekspor netto.

Ketenagakerjaan merupakan aspek yang sangat penting untuk dikaji. Negara dengan jumlah penduduk yang sangat besar serta penyediaan kesempatan kerja yang terbatas akan menghadapi masalah yang serius dengan tingkat pengangguran. Perkembangan yang terjadi dalam jumlah angkatan kerja (AK) tidak bisa dilepaskan dari laju pertumbuhan jumlah penduduk di suatu wilayah. Tjiptoherijanto (2001) menyatakan bahwa selama periode 1997 - 1999 jumlah angkatan kerja di Indonesia cenderung meningkat, baik yang bekerja maupun yang mencari pekerjaan. Bila dilihat antara jumlah penduduk yang bekerja dan yang sedang mencari pekerjaan, ternyata banyaknya penduduk yang bekerja relatif lebih besar dibandingkan dengan yang mencari pekerjaan, namun peningkatannya jauh lebih tinggi peningkatan penduduk yang mencari pekerjaan. Dalam pembangunan, penduduk juga berfungsi sebagai tenaga kerja maka akan timbul masalah dalam penyediaan lapangan kerja. Dengan demikian bertambahnya jumlah penduduk di Indonesia dari tahun ke tahun sedangkan jumlah lapangan kerja yang tersedia terbatas dapat menimbulkan persaingan di antara pencari kerja dan terancam kurangnya kesempatan pemenuhan kesejahteraan sehingga dikhawatirkan meningkatkan kemiskinan. Sebagaimana yang diungkapkan oleh Ngangi (2010) bahwa mengatasi kemiskinan bukanlah pekerjaan yang mudah tapi berhubungan erat dengan masalah kehidupan seperti keadaan suatu tempat, aktivitas sosial, tingkat pendidikan dan status kesehatan. Kualitas tenaga kerja dicerminkan salah satunya oleh adanya perbaikan pendidikan. Semakin tinggi pendidikan formal 
yang diperoleh, maka produktivitas tenaga kerja akan semakin tinggi pula. Hal tersebut sesuai dengan teori human capital (modal manusia)

Sendouw (2006) menyatakan bahwa sebagai sebuah negara, Indonesia merupakan salah satu negara yang memiliki kekayaan alam terbesar di dunia tapi hal ini belum menjamin tercapainya kesejahteraan masyarakat. Bukan pula tergantung dari umur negara tersebut melainkan dapat tercermin dari sikap dan perilaku mengikuti prinsip - prinsip dasar kehidupan. Sikap dan perilaku yang ditunjukkan oleh tiap manusia dapat terbentuk melalui proses pembelajaran khususnya di bangku pendidikan formal sehingga menciptakan modal manusia yang mengikuti prinsip dasar kehidupan.

Fenomena inflasi di Indonesia masih menjadi satu dari berbagai "penyakit" ekonomi makro yang meresahkan pemerintah terlebih bagi masyarakat. Menjelang akhir pemerintahan Orde Baru (sebelum krisis moneter) angka inflasi tahunan dapat ditekan sampai pada single digit, tetapi secara umum masih mengandung kerawanan jika dilihat dari seberapa besar persentase kelompok masyarakat golongan miskin yang menderita akibat inflasi.

Sejak tahun 1967, Indonesia berusaha membuka diri. Perubahan sistem terisolasi menjadi sistem terbuka masih mengandung keuntungan yang meragukan. Nilai ekspor netto Indonesia selama 2 dasawarsa berfluktuasi dan selama periode tahun 2005 - 2010, neraca perdagangan (ekspor netto) Indonesia mengalami surplus perdagangan. Berdasarkan ulasan beberapa indikator karakteristik regional tersebut maka diperlukan telaah sekelompok gejala yang terdapat bersamaan pada satu region guna memperoleh pemahaman suatu fakta secara keseluruhan yang dapat ditentukan dan diidentifikasi melalui analisa pengaruh karakteristik regional sehingga kiranya dapat memacu pertumbuhan ekonomi demi mewujudkan eksistensi dalam perekonomian suatu wilayah.

Paper ini berupaya menganalisis bagaimana pengaruh laju pertumbuhan angkatan kerja, laju pertumbuhan penduduk, laju pertumbuhan modal manusia, laju pertumbuhan inflasi, dan laju pertumbuhan ekspor netto terhadap pertumbuhan ekonomi di Indonesia. Penelitian ini diharapkan mampu memberikan kontribusi kepada para pengambil kebijakan dalam memberikan informasi mengenai faktor-faktor yang mempengaruhi pertumbuhan ekonomi suatu wilayah serta bagi ilmu pengetahuan guna menambah khasanah ilmu ekonomi khususnya ekonomi pembangunan dan ekonomi regional dan dapat melengkapi kajian pertumbuhan ekonomi wilayah dengan mengungkap secara empiris faktor-faktor yang mempengaruhinya.

Bagian kedua dari paper ini mengulas teori dan studi literatur, sementara bagian ketiga mengulas metodologi dan data yang digunakan. Bagian keempat menyajikan hasil estimasi dan analisisnya sementara kesimpulan dan saran disajikan pada bagian terakhir. 


\section{TEORI}

Pertumbuhan ekonomi mengukur prestasi dari perkembangan suatu perekonomian. Pengukuran akan kemajuan sebuah perekonomian memerlukan alat ukur yang tepat, berupa alat pengukur pertumbuhan ekonomi antara lain yaitu Produk Domestik Bruto (PDB) atau di tingkat regional disebut dengan Produk Domestik Regional Bruto (PDRB) yaitu jumlah barang atau jasa yang dihasilkan oleh suatu perekonomian dalam jangka waktu satu tahun dan dinyatakan dalam harga pasar.

Menurut ekonomk klasik, Smith, pertumbuhan ekonomi secara klasik dipengaruhi oleh dua faktor utama yakni pertumbuhan output total dan pertumbuhan penduduk. Pertumbuhan ekonomi sangat dipengaruhi oleh produktivitas sektor-sektor dalam menggunakan faktor-faktor produksinya. Produktivitas dapat ditingkatkan melalui berbagai sarana pendidikan, pelatihan dan manajemen yang lebih baik (Sukirno, 2008)

Menurut teori pertumbuhan neo klasik tradisional, pertumbuhan output selalu bersumber dari satu atau lebih dari tiga faktor yakni kenaikan kualitas dan kuantitas tenaga kerja, penambahan modal (tabungan dan investasi) dan penyempurnaan teknologi (Todaro dan Smith, 2008)

Mankiw, Romer dan Weil (MRW) melakukan modifikasi terhadap model pertumbuhan neo klasik dimana mereka mengusulkan pemakaian variabel akumulasi modal manusia (human capital). Sumber pertumbuhan ekonomi dengan demikian berasal dari pertumbuhan kapital, tenaga kerja dan modal manusia. Hasil estimasi yang dihasilkan dari model MRW ternyata lebih baik dibandingkan dengan model neo klasik (Mankiw, 2006)

Teori pertumbuhan baru memberikan kerangka teoritis untuk menganalisis pertumbuhan yang bersifat endogen. Pertumbuhan ekonomi merupakan hasil dari dalam sistem ekonomi. Kemajuan teknologi merupakan hal yang endogen, pertumbuhan merupakan bagian dari keputusan pelaku-pelaku ekonomi untuk berinvestasi dalam pengetahuan. Peran modal lebih besar dari hanya sekedar bagian dari pendapatan apabila modal yang tumbuh bukan hanya modal fisik saja tapi menyangkut modal manusia. Akumulasi modal merupakan sumber utama pertumbuhan ekonomi (Mankiw, 2006)

Laju pertumbuhan penduduk dan hal-hal yang berhubungan dengan kenaikan jumlah angkatan kerja (labor force) secara tradisional telah dianggap sebagai faktor yang positif dalam merangsang pertumbuhan ekonomi. Kebenaran hubungan yang positif tersebut tergantung pada kemampuan sistem ekonomi untuk menyerap dan mempekerjakan tambahan pekerja secara produktif. Teori neoklasik menyatakan bahwa tenaga kerja merupakan salah satu faktor yang menjelaskan tinggi rendahnya pertumbuhan ekonomi. Sodik et al (2007) dalam penelitiannya berusaha memeriksa pengaruh aglomerasi dalam pertumbuhan ekonomi regional. Hasilnya menunjukkan bahwa pertumbuhan ekonomi regional salah satunya dipengaruhi oleh angkatan kerja. Teori Solow (Neo Klasik) juga menyatakan bahwa laju pertumbuhan angkatan kerja 
berpengaruh positif dan signifikan terhadap pertumbuhan ekonomi, yang disebabkan melalui semakin banyaknya angkatan kerja yang bekerja, maka kemampuan untuk menghasilkan output semakin tinggi. Dengan banyaknya output yang mampu dihasilkan, maka akan mendorong tingkat penawaran agregat sehingga akan mendorong pertumbuhan ekonomi.

Secara umum, laju pertumbuhan penduduk dianggap sebagai salah satu faktor positif yang memacu pertumbuhan ekonomi. Meski demikian, peran laju pertumbuhan penduduk terhadap pembangunan ekonomi sepenuhnya tergantung pada kemampuan sistem perekonomian untuk menyerap dan secara produktif memanfaatkan tambahan tenaga kerja. Adapun kemampuan itu sendiri lebih lanjut dipengaruhi oleh tingkat jenis akumulasi modal dan tersedianya input atau faktor penunjang seperti kecakapan manajerial dan administrasi.

Selain jumlah penduduk, peran tenaga kerja terhadap pertumbuhan PDB juga sangat tergantung pada kualitas tenaga kerja tersebut. Teori Human Capital menjelaskan bahwa seseorang dapat meningkatkan penghasilannya melalui jenjang pendidikan yang lebih tinggi. Selain penundaan penerimaan penghasilan, orang yang melanjutkan pendidikan harus membayar biaya secara langsung. Setelah tamat dari pendidikan yang ditempuhnya, sangat diharapkan seseorang itu bisa mendapatkan penghasilan yang lebih tinggi dan berujung pada pertumbuhan ekonomi di daerahnya. Semakin tinggi tingkat pendidikan penduduk mempunyai pengaruh positif terhadap pertumbuhan ekonomi. Laju pertumbuhan modal manusia dipandang sebagai mesin pertumbuhan utama yang memiliki peranan menggerakkan dan mendorong pertumbuhan ekonomi. Teori Solow menyatakan bahwa laju pertumbuhan modal manusia berpengaruh positif terhadap pertumbuhan ekonomi, yang disebabkan modal manusia merupakan input kunci pokok untuk sector riset sehingga ditemukan produk atau ide baru. Dengan demikian, negara-negara dengan stock awal modal manusia yang lebih tinggi, ekonominya tumbuh lebih cepat. Sehingga modal manusia disadari merupakan sumber pertumbuhan yang penting dalam teori pertumbuhan endogen. Modal manusia merujuk pada stok pengetahuan dan keterampilan berproduksi seseorang. Pendidikan adalah salah satu cara dimana individu meningkatkan modal manusianya. Argumen yang disampaikan pendukung teori ini ialah manusia yang memiliki tingkat pendidikan yang lebih tinggi, yang diukur juga dengan lamanya waktu sekolah, akan memiliki pekerjaan dan upah yang lebih baik dibanding yang pendidikannya lebih rendah. Apabila upah mencerminkan produktivitas, maka semakin banyak orang yang memiliki pendidikan tinggi, semakin tinggi produktivitas dan hasilnya ekonomi nasional akan bertumbuh lebih tinggi. Semakin tinggi pendidikan seseorang, diharapkan stok modal manusianya semakin tinggi. Dikarenakan modal manusia memiliki hubungan positif dengan pertumbuhan ekonomi maka implikasinya pendidikan juga memiliki hubungan positif dengan produktivitas atau pertumbuhan ekonomi.

Ekonomi yang berorientasi ekspor dapat dipahami melalui export-led growth yang merupakan kebijakan ekonomi dan perdagangan yang bertujuan untuk mempercepat proses industrialisasi suatu negara dengan mengekspor barang-barang yang memiliki keunggulan 
komparatif. Export-led growth membuka pasar domestik untuk kompetisi asing dalam pertukaran untuk akses pasar di Negara lain. Export-led growth merupakan strategi ekonomi yang digunakan oleh beberapa Negara berkembang. Strategi ini berusaha untuk menemukan ceruk dalam perekonomian dunia untuk ekspor jenis tertentu. Industri yang menghasilkan ekspor dapat menerima subsidi pemerintah dan akses yang lebih baik ke pasar lokal. Dengan menerapkan strategi ini, negara-negara berharap untuk mendapatkan mata uang yang lebih kuat untuk mengimpor komoditi yang diproduksi lebih murah di tempat lain. Export-led growth memiliki dua alasan penting yaitu dapat menghasilkan keuntungan dan memungkinkan suatu negara untuk menyeimbangkan keuangan mereka bahkan melebihi utang mereka asalkan fasilitas dan bahan-bahan untuk diekspor tersedia. Selain itu, alasan yang jauh lebih penting diperdebatkan yaitu peningkatan pertumbuhan ekspor dapat memicu produktivitas yang lebih besar. Pentingnya konsep ini dibahas dalam model oleh J.S.L McCombie dan A.P. Thirwall's (1994) dalam Economic Growth and the Balance-of-Payments Constraint. Pada dasarnya ada dua jenis ekspor yang digunakan dalam konteks ini yaitu barang-barang manufaktur dan bahan baku.

Neraca perdagangan (balance of trade) adalah sebuah istilah yang digunakan untuk menggambarkan perbedaan antara nilai moneter antara ekspor dan impor. Neraca perdagangan biasa disebut dengan ekspor netto. Neraca perdagangan yang positif berarti negara tersebut mengalami ekspor yang nilai moneternya melebihi impor, dan biasa disebut surplus perdagangan. Sementara itu jika neraca perdagangan menunjukkan kondisi negatif artinya nilai moneter impor melebihi ekspor, dan disebut sebagai defisit perdagangan. Bagi setiap negara tentunya kondisi surplus lebih diharapkan. Dengan terjadinya surplus perdagangan berarti jumlah ekspor yang dilakukan oleh sebuah negara lebih banyak dibandingkan impor. Kondisi ini berpengaruh positif terhadap pertumbuhan ekonomi negara tersebut.

Faktor lain yang berpengaruh terhadap pertumbuhan ekonomi adalah tingkat harga. Dalam perekonomian, proses meningkatnya harga-harga secara umum dan terus-menerus terkait dengan proses dan mekanisme yang terjadi dalam pasar, yang berpengaruh terhadap penurunan nilai mata uang. Inflasi sesungguhnya mencerminkan kestabilan nilai sebuah mata uang yang tercermin dari stabilitas tingkat harga yang kemudian berpengaruh terhadap realisasi pencapaian tujuan pembangunan ekonomi suatu negara, seperti perluasan kesempatan kerja dan stabilitas ekonomi. Secara empiris menurut Sodik et al (2007), pertumbuhan ekonomi regional salah satunya dipengaruhi oleh tingkat inflasi. Sodik dan Nuryadin (2005) menyimpulkan bahwa laju inflasi tidak berpengaruh terhadap pertumbuhan ekonomi regional, hanya pada periode pengamatan 2000 - 2003 (Setelah otonomi daerah) berpengaruh terhadap pertumbuhan ekonomi dengan tanda yang negatif.

Mengacu pada uraian di atas, peran laju pertumbuhan penduduk, akumulasi modal manusia, tingkat inflasi, dan ekspor terhadap pertumbuhan ekonomi secara singkat dapat diilustrasikan pada gambar berikut: 


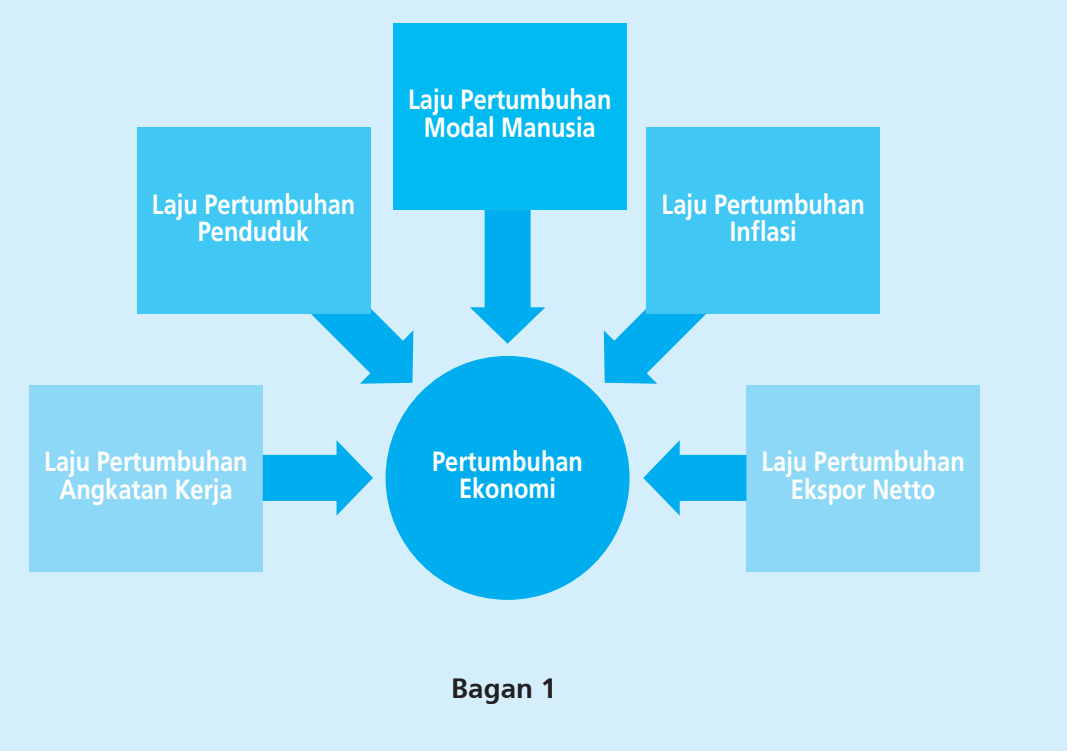

\section{METODOLOGI}

\section{Data dan Variabel}

Penelitian ini dilakukan melalui pengumpulan data sekunder di instansi terkait (BPS Provinsi Sulawesi Utara) di Kota Manado Provinsi Sulawesi Utara. Waktu pelaksanaan penelitian dilaksanakan pada bulan Februari tahun 2012 sampai dengan April tahun 2012.

Jenis yang dipergunakan adalah data tahunan mencakup periode 2006 - 2010 dari 33 provinsi yang ada di Indonesia, meliputi variabel-variabel berikut:

a. Laju Pertumbuhan Produk Domestik Regional Bruto atas dasar harga konstan 2000 menurut Provinsi di Indonesia tahun 2006-2010

b. Jumlah Angkatan Kerja Penduduk berumur 15 tahun ke atas menurut Provinsi di Indonesia tahun 2006-2010

C. Jumlah Pertumbuhan Penduduk menurut Provinsi di Indonesia tahun 2006 - 2010

d. Jumlah Mahasiswa Negeri dan Swasta di bawah Kementerian Pendidikan Nasional menurut Provinsi di Indonesia tahun 2006-2010

e. Laju Inflasi menurut Provinsi di Indonesia tahun 2006-2010

f. Nilai Ekspor dan Impor menurut Provinsi di Indonesia tahun 2006 - 2010 


\section{Teknik Estimasi}

Studi ini menggunakan alat analisis statistik regresi data panel. Uji statistik F (Uji Chow) dan Uji Hausman digunakan untukmemilih antara model common effect atau model fixed effect, (Hausman, 2001). Model empiris yang diestimasi adalah:

$$
Y_{i t}=\alpha_{o i}+\beta_{1} x_{1 i t}+\beta_{2} x_{2 i t}+\beta_{3} x_{3 i t}+\beta_{4} x_{4 i t}+\beta_{5} x_{5 i t}+\varepsilon_{i t}
$$

dimana $Y$ adalah laju pertumbuhan PDRB; $x_{1}$ adalah laju pertumbuhan angkatan kerja; $\mathrm{x}_{2}$ adalah laju pertumbuhan penduduk; $\mathrm{x}_{3}$ adalah laju pertumbuhan modal manusia; $\mathrm{x}_{4}$ adalah laju inflasi; dan $x_{5}$ adalah laju pertumbuhan ekspor netto. Notasi i dan $t$ menunjukkan identifier (dalam hal ini provinsi) dan waktu.

\section{HASIL DAN ANALISIS}

Pengujian data penelitian yaitu dengan menggunakan jenis model estimasi berupa model common effect dengan model fixed effect, model fixed effect dengan model random effect dan model fixed effect dengan weighted least square. Hasil terbaik dengan beberapa pengujian digunakan untuk merumuskan kesimpulan dalam penelitian ini.

Dari hasil perhitungan dengan menggunakan estimasi model common effect dengan model fixed effect, dengan bantuan software EViews 5.1 diperoleh hasil persamaan untuk pertumbuhan ekonomi Indonesia ialah sebagai berikut :

\begin{tabular}{|c|c|c|c|c|}
\hline \multicolumn{5}{|c|}{$\begin{array}{c}\text { Tabel } 1 \\
\text { Estimasi Model Common Effect dan Model Fixed Effect }\end{array}$} \\
\hline Variable & Coeficient & Std. Error & t-Statistic & Prob. \\
\hline C & 8,7143 & 1,8352 & 4,7483 & 0,0000 \\
\hline INFLASI & $-0,1518$ & 0,0780 & $-1,9457$ & 0,0539 \\
\hline KERJA & 0,0688 & 0,0298 & 2,3091 & 0,0226 \\
\hline PENDIDIKAN & $-0,0022$ & 0,0093 & $-0,2349$ & 0,8147 \\
\hline NETTO & 0,0008 & 0,0007 & 1,1520 & 0,2515 \\
\hline PENDUDUK & $-1,1043$ & 0,9193 & $-1,2012$ & 0,2319 \\
\hline \multicolumn{5}{|c|}{ Cross-section fixed (dummy variables) } \\
\hline R-squared & 0,3874 & \multicolumn{2}{|c|}{ Mean dependent var } & 5,7153 \\
\hline Adjusted R-squared & 0,2089 & \multicolumn{2}{|c|}{ S.D. dependent var } & 3,5803 \\
\hline S.E. of regression & 3,1842 & \multicolumn{2}{|c|}{ Akaike info criterion } & 5,3531 \\
\hline Sum squared resid & 1287,737 & \multicolumn{2}{|c|}{ Schwarz criterion } & 6,0684 \\
\hline Log likelihood & $-403,637$ & \multicolumn{2}{|l|}{ F-statistic } & 2,1711 \\
\hline Durbin-Watson stat & 2,4586 & \multicolumn{2}{|c|}{ Prob(F-statistic) } & 0,0007 \\
\hline
\end{tabular}


Hasil estimasi model pada Tabel 3 menggambarkan bahwa terdapat 1 variabel yang signifikan pada $\alpha=5$ persen, yaitu laju pertumbuhan angkatan kerja sedangkan laju pertumbuhan inflasi signifikan pada $\alpha=10$ persen. Sementara 3 variabel lain tidak signifikan pada $\alpha=5$ persen yaitu modal manusia (pendidikan), ekspor netto dan jumlah penduduk. Dari hasil estimasi, $R^{2}$ yang dihasilkan dari estimasi persamaan dalam penelitian ini relatif kecil yakni hanya sebesar 38,74 persen selama masa periode pengamatan. Hal ini dapat diartikan bahwa dengan metode analisis model common effect dengan model fixed effect, variasi variabel independen dalam penelitian ini hanya mampu menjelaskan sebesar 38,74 persen variasi variabel dependen sementara sisanya sebesar 61,26 persen dijelaskan oleh variabel lain yang tidak diikutsertakan dalam model penelitian.

Untuk menentukan pilihan estimasi yang digunakan yaitu dengan melakukan Uji Chow. Dari uji ini diharapkan dapat diketahui pilihan yang lebih tepat antara model common effect dengan model fixed effect. Pengujian yang dilakukan menggunakan Uji Chow yaitu :

Ho : model mengikuti common effect

H1 : model mengikuti fixed effect

Berikut ialah hasil Uji Chow :

\begin{tabular}{l|r|r|r}
\multicolumn{2}{c}{$\begin{array}{c}\text { Tabel } 2 \\
\text { Uji Chow }\end{array}$} & \multicolumn{1}{c}{ Prob. } \\
\hline \multicolumn{1}{c|}{ Effects Test } & Statistic & d.f. & 0,0003 \\
\hline Cross-section F & 2,3828 & $(32,127)$ & 0,0000 \\
Cross-section Chi-square & 77,5923 & 32 &
\end{tabular}

Hasil tersebut menunjukkan baik $F$ test maupun chi square signifikan ( $p$-value 0,0003 dan 0,0000 kurang dari $\alpha=5$ persen) sehinggaHo ditolak dan $\mathrm{H} 1$ diterima, maka model mengikuti fixed effect. Berdasarkan hasil estimasi maka disimpulkan bahwa teknik estimasi yang lebih baik untuk digunakan dalam penelitian ini ialah dengan menggunakan model fixed effect.

Kemudian dilanjutkan dengan melakukan teknik estimasi menggunakan model random effect. Dari hasil perhitungan dengan menggunakan model estimasi fixed effect dengan model random effect, dengan bantuan software EViews 5.1 diperoleh hasil persamaan untuk pertumbuhan ekonomi Indonesia ialah sebagai berikut: 


\begin{tabular}{|c|c|c|c|c|}
\hline \multicolumn{5}{|c|}{$\begin{array}{c}\text { Tabel } 3 \\
\text { Estimasi Model Fixed Effect dan Model Random Effect }\end{array}$} \\
\hline Variable & Coeficient & Std. Error & t-Statistic & Prob. \\
\hline $\mathrm{C}$ & 6,5333 & 0,9214 & 7,0902 & 0,0000 \\
\hline INFLASI & $-0,1092$ & 0,0737 & $-1,4805$ & 0,1407 \\
\hline KERJA & 0,0468 & 0,0279 & 1,6719 & 0,0965 \\
\hline PENDIDIKAN & 0,0027 & 0,0088 & 0,3118 & 0,7555 \\
\hline NETTO & 0,0005 & 0,0006 & 0,8365 & 0,4041 \\
\hline PENDUDUK & $-0,0992$ & 0,3564 & $-0,2784$ & 0,7810 \\
\hline \multicolumn{5}{|l|}{ Weighted Statistics } \\
\hline R-squared & 0,0348 & \multicolumn{2}{|c|}{ Mean dependent var } & 3,9819 \\
\hline Adjusted R-squared & 0,0045 & \multicolumn{2}{|c|}{ S.D. dependent var } & 3,2533 \\
\hline S.E. of regression & 3,2460 & \multicolumn{2}{|c|}{ Sum squared resid } & 1675,341 \\
\hline F-statistic & 1,1483 & \multicolumn{2}{|c|}{ Durbin-Watson stat } & 1,9370 \\
\hline Prob(F-statistic) & 0,3372 & & & \\
\hline
\end{tabular}

Berdasarkan hasil estimasi model fixed effect dengan model random effect, memberikan hasil bahwa tidak ada variabel yang signifikan pada $\alpha=5$ persen tapi angkatan kerja signifikan pada $\alpha=10$ persen. Dari hasil estimasi, $\mathrm{R}^{2}$ yang dihasilkan dari estimasi persamaan dalam penelitian ini sangat kecil yakni hanya sebesar 3,48 persen selama masa periode pengamatan. Hal ini dapat diartikan bahwa dengan metode analisis model fixed effect dengan model random effect, variasi variabel independen dalam penelitian ini hanya mampu menjelaskan sebesar3,48 persen variasi variabel dependen yaitu pertumbuhan ekonomi Indonesia, sementara sisanya sebesar 96,52 persen dijelaskan oleh variabel lain yang tidak diikutsertakan dalam model penelitian.

Untuk menentukan pilihan estimasi yang digunakan maka dilakukan uji Hausman. Dari uji ini diharapkan dapat diketahui pilihan yang lebih tepat antara model fixed effect dengan model random effect.

Berdasarkan hasil uji Hausman diatas menunjukkan bahwa untuk periode pengamatan 2006 - 2010 hasil pengujian tersebut signifikan ( $p$-value 0.0471 kurang dari $\alpha=5$ persen) sehingga Ho ditolak dan $\mathrm{H} 1$ diterima sehingga estimasi menunjukkan bahwa pendekatan model fixed effect lebih baik dibandingkan dengan pendekatan model random effect. Berarti terdapat perbedaan antar unit yang dapat dilihat melalui perbedaan dalam constans term. Model fixed effect diasumsikan hanya fokus pada individual spesific effect.

Pengujian dilakukan menggunakan Uji Hausman memiliki hipotesanol yaitu model mengikuti random effect dan alternatifnya model mengikuti fixed effect. Hasilnya menunjukkan bahwa model yang lebih sesuai adalah Fixed Effect Model $(p=0,0471)$. 
Dalam penelitian dengan menggunakan cross section data, memungkinkan kecenderungan terdapatnya heteroskedastisitas dalam data penelitian (data tidak homoskedastisitas) maka perlu dilakukan teknik estimasi dengan menggunakan model fixed effect dengan weighted least square atau sering disebut dengan general least square (GLS).

\begin{tabular}{|c|c|c|c|c|}
\hline \multicolumn{5}{|c|}{$\begin{array}{c}\text { Tabel } 4 \\
\text { Model Fixed Effect dengan Weighted Least Square (GLS) }\end{array}$} \\
\hline Variable & Coeficient & Std.Error & t-Statistic & Prob. \\
\hline C & 5,7478 & 0,5775 & 9,9515 & 0,0000 \\
\hline INFLASI & $-0,0173$ & 0,0176 & $-0,9818$ & 0,3280 \\
\hline KERJA & 0,0431 & 0,0117 & 3,6633 & 0,0004 \\
\hline PENDIDIKAN & 0,0012 & 0,0018 & 0,6726 & 0,5024 \\
\hline NETTO & 0,0003 & 0,0001 & 2,8297 & 0,0054 \\
\hline PENDUDUK & $-0,0207$ & 0,3048 & $-0,0680$ & 0,9458 \\
\hline \multicolumn{5}{|l|}{ Weighted Statistics } \\
\hline R-squared & 0,8292 & \multicolumn{2}{|c|}{ Mean dependent var } & 20,6755 \\
\hline Adjusted R-squared & 0,7795 & \multicolumn{2}{|c|}{ S.D. dependent var } & 16,6059 \\
\hline S.E. of regression & 2,5174 & \multicolumn{2}{|c|}{ Sum squared resid } & 804,8951 \\
\hline F-statistic & 16,6710 & \multicolumn{2}{|c|}{ Durbin-Watson stat } & 2,8283 \\
\hline Prob(F-statistic) & 0,0000 & & & \\
\hline
\end{tabular}

Berdasarkan hasil olahan data untuk estimasi persamaan pertumbuhan ekonomi Indonesia dengan model fixed effect dengan weighted least square (GLS), diperoleh hasil yang lebih baik. Hasil estimasi model menggambarkan bahwa terdapat 2 variabel yang signifikan pada $\alpha$ = 5 persen, yaitu laju pertumbuhan angkatan kerja dan ekspor netto. Model estimasi ini juga memberi gambaran bahwa ada 18 provinsi yang pertumbuhan ekonominya positif.

Pada model fixed effect dengan weighted least square terdapat intercept yang berbeda. Dengan kata lain, intercept ini mungkin berbeda untuk setiap individu. Pemikiran inilah yang menjadi dasar pemikiran pembentukan model fixed effect. Kelebihan model ini ialah dapat membedakan efek individual. 
1. Uji Statistik

\begin{tabular}{|c|c|c|c|c|}
\hline \multicolumn{5}{|c|}{$\begin{array}{c}\text { Tabel } 5 \\
\text { Hasil Estimasi Model }\end{array}$} \\
\hline \multicolumn{5}{|c|}{ Dependent Variable : Y } \\
\hline Variable & Coefficient & Std. Error & t-Statistic & Prob. \\
\hline C & 5,7478 & 0,6289 & 9,1384 & $0,0000^{* *}$ \\
\hline INFLASI & $-0,0173$ & 0,0298 & $-0,5797$ & 0,3280 \\
\hline KERJA & 0,0431 & 0,0169 & 2,5518 & $0,0004^{*}$ \\
\hline PENDIDIKAN & 0,0012 & 0,0017 & 0,6840 & 0,5024 \\
\hline NETTO & 0,0003 & 0,0001 & 2,3490 & $0,0054^{*}$ \\
\hline PENDUDUK & $-0,0207$ & 0,3142 & $-0,0660$ & 0,9458 \\
\hline R-squared & 0,8292 & \multicolumn{2}{|c|}{ F-statistic } & 16,6710 \\
\hline Adjusted R-squared & 0,7795 & \multicolumn{2}{|c|}{ Prob (F-statistic) } & $0,0000^{* *}$ \\
\hline
\end{tabular}

a. Koefisien Determinasi (Uji $\left.R^{2}\right)$.

Nilai $R^{2}$ ialah sebesar 82,92 artinya bahwa sebesar 82,92 persen variabel pertumbuhan ekonomi bisa dijelaskan oleh variabel laju pertumbuhan inflasi, angkatan kerja, modal manusia, ekspor netto, dan penduduk. Sedangkan sisanya sebesar 17,08 persen bisa dijelaskan oleh variabel lain diluar model.

b. Pengujian Signifikansi Simultan (Uji F).

F statistik dalam EViews merupakan F hitung. Jika nilai p-value kurang dari a maka hipotesis tersebut ditolak (signifikan berbeda dengan nol). Dari hasil uji Prob F-statistik diperoleh bahwa nilai Prob F-statistik signifikan pada $\alpha=1$ persen, hal ini mengindikasikan bahwa secara keseluruhan, semua variabel independen mampu menjelaskan variabel dependennya yaitu pertumbuhan ekonomi.

\section{Pembahasan}

Interpretasi ekonomi dari persamaan yang diperoleh ialah nilai konstanta sebesar 5,75 menunjukkan bahwa jika variabel-variabel independen dianggap konstan, maka rata-rata pertumbuhan ekonomi Indonesia ialah sebesar 5,75 persen.

a. Pengaruh Laju Pertumbuhan Angkatan Kerja terhadap Pertumbuhan Ekonomi.

Berdasarkan hasil estimasi regresi berganda data panel, menunjukkan bahwa variabel laju pertumbuhan angkatan kerja positif dan signifikan terhadap pertumbuhan ekonomi di Indonesia pada tahun 2006 - 2010. Koefisien variabel dari laju pertumbuhan angkatan kerja (AK) ialah 0,0431 maka laju pertumbuhan angkatan kerja berpengaruh positif 
terhadap pertumbuhan ekonomi Indonesia secara signifikan. Jika laju pertumbuhan AK naik 1 persen, maka pertumbuhan ekonomi Indonesia naik sebesar 0,0431 persen. Hal ini memberikan sinyal bahwa kontribusi angkatan kerja di Indonesia bagi pertumbuhan ekonomi Indonesia ialah signifikan. Hal ini sesuai dengan hipotesis penelitian yang telah dirumuskan sebelumnya serta sesuai dengan penelitian yang dilakukan oleh Sodik et al (2007). Hal ini juga sesuai dengan teori Solow (neo klasik) yang menyatakan bahwa laju pertumbuhan angkatan kerja berpengaruh positif dan signifikan terhadap pertumbuhan ekonomi, yang disebabkan melalui semakin banyaknya angkatan kerja yang bekerja, maka kemampuan untuk menghasilkan output semakin tinggi. Dengan banyaknya output yang mampu dihasilkan, maka akan mendorong tingkat penawaran agregat sehingga akan mendorong pertumbuhan ekonomi. Pengaruh signifikan dari angkatan kerja terhadap pertumbuhan ekonomi terutama disebabkan oleh posisi angkatan kerja sebagai salah satu faktor produksi yang menggerakkan perekonomian di daerah.

b. Pengaruh Laju Pertumbuhan Penduduk terhadap Pertumbuhan Ekonomi.

Berdasarkan hasil estimasi regresi berganda data panel, menunjukkan bahwa variabel laju pertumbuhan penduduk negatif dan tidak signifikan terhadap pertumbuhan ekonomi di Indonesia pada tahun 2006 - 2010. Koefisien variabel dari laju pertumbuhan penduduk ialah - 0,0207 dan nilai ini ialah negatif, maka laju pertumbuhan penduduk cenderung berpengaruh negatif terhadap pertumbuhan ekonomi Indonesia secara tidak signifikan. Hasil penelitian yang diperoleh sesuai dengan penelitian yang dilakukan oleh Simamora dan Sirojuzilam (2008) yang menunjukkan bahwa laju pertumbuhan penduduk tidak memiliki pengaruh signifikan terhadap pertumbuhan ekonomi regional. Pengaruh tidak signifikannya laju pertumbuhan penduduk terhadap pertumbuhan ekonomi disebabkan antara lain rendahnya kualitas modal manusiaangkatan kerja yang melakukan aktivitas ekonomi. Penduduk yang besar dengan kualitas penduduk yang rendah menyebabkan penduduk tersebut menjadi beban bagi pertumbuhan ekonomi dan bukan pemacu. Menurut teori-teori pertumbuhan ekonomi salah satunya ditentukan oleh laju pertumbuhan penduduk. Faktor laju pertumbuhan penduduk tidak selalu memberikan sumbangan yang positif terhadap pertumbuhan ekonomi.

c. Pengaruh Laju Pertumbuhan Modal Manusia terhadap Pertumbuhan Ekonomi.

Berdasarkan hasil estimasi regresi berganda data panel, menunjukkan bahwa koefisien variabel dari laju pertumbuhan modal manusia ialah 0,0012 maka laju pertumbuhan modal manusia cenderung berpengaruh positif terhadap pertumbuhan ekonomi Indonesia secara tidak signifikan. Teori Solow menyatakan bahwa laju pertumbuhan modal manusia berpengaruh positif terhadap pertumbuhan ekonomi. Modal manusia merujuk pada stok pengetahuan dan keterampilan berproduksi seseorang. Pendidikan ialah salah satu cara dimana individu meningkatkan modal manusianya. Semakin tinggi pendidikan seseorang, diharapkan stok modal manusianya semakin tinggi. Hasil penelitian yang diperoleh sesuai 
dengan penelitian yang dilakukan Gama (2007) yang menghasilkan estimasi bahwa tingkat pendidikan tidak signifikan. Hasil penelitian ini juga sejalan dengan penelitian yang dilakukan Bhinadi (2003) yang menyatakan bahwa laju pertumbuhan modal manusia tidak signifikan terhadap pertumbuhan ekonomi. Sodik et al (2007) juga melakukan penelitian yang hasil estimasi datanya menunjukan bahwa variabel tingkat pendidikan tidak berpengaruh signifikan terhadap pertumbuhan ekonomi. Sugiarto (2011) dalam penelitiannya menyatakan bahwa laju pertumbuhan modal manusia berpengaruh positif terhadap pertumbuhan ekonomi Indonesia tapi tidak signifikan secara statistik sehingga dapat dinyatakan bahwa laju pertumbuhan modal manusia tidak berpengaruh secara signifikan terhadap pertumbuhan ekonomi Indonesia. Pengaruh tidak signifikannya laju pertumbuhan modal manusia terhadap pertumbuhan ekonomi antara lain disebabkan karena tidak digunakannya lag jumlah mahasiswa yang sedang menempuh studi di perguruan tinggi. Hal ini mengindikasikan jumlah mahasiswa yang belum menamatkan studi dari perguruan tinggi merupakan variabel yang kurang tepat menggambarkan teori human capital.

d. Pengaruh Laju Pertumbuhan Inflasi terhadap Pertumbuhan Ekonomi.

Berdasarkan hasil estimasi regresi berganda data panel, menunjukkan bahwa variabel laju pertumbuhan inflasi negatif dan tidak signifikan terhadap pertumbuhan ekonomi di Indonesia pada tahun 2006 - 2010. Koefisien variabel dari laju pertumbuhan inflasi adalah $-0,0173$ dan nilai ini ialah negatif, maka laju pertumbuhan inflasi cenderung berpengaruh negatif terhadap pertumbuhan ekonomi Indonesia secara tidak signifikan. Hasil yang diperoleh sesuai dengan penelitian yang dilakukan oleh Sodik dan Nuryadin (2005) yaitu variabel laju inflasi tidak berpengaruh terhadap pertumbuhan ekonomi regional dengan tanda yang negatif.Pengaruh tidak signifikannya laju pertumbuhan inflasi terhadap pertumbuhan ekonomi antara lain disebabkan karena inflasi (demand pull) pada rate yang wajar menunjukkan tanda peningkatan pendapatan. Jadi, karena bukan hiperinflasi maka tidak sampai menggerus pertumbuhan (growth).

e. Pengaruh Laju Pertumbuhan Ekspor Netto terhadap Pertumbuhan Ekonomi.

Berdasarkan hasil estimasi regresi berganda data panel, menunjukkan bahwa variabel laju pertumbuhan ekspor netto positif dan signifikan terhadap pertumbuhan ekonomi di Indonesia pada tahun 2006 - 2010. Koefisien variabel dari laju pertumbuhan ekspor netto ialah 0,0003 dan nilai ini ialah positif, maka laju pertumbuhan ekspor netto berpengaruh positif terhadap pertumbuhan ekonomi Indonesia secara signifikan. Jika laju pertumbuhan ekspor netto naik 1 persen, maka pertumbuhan ekonomi Indonesia naik sebesar 0,0003 persen. Hasil penelitian ini sesuai dengan penelitian yang dilakukan oleh Sodik dan Nuryadin (2006) dimana variabel eskpor netto merupakan proxy dari keterbukaan perekonomian daerah yang memiliki arah konsisten dengan hipotesis dan teori meskipun memiliki nilai koefisien yang relatif kecil. Nilai koefisien regresi yang kecil disebabkan oleh selisih dari nilai ekspor yang tidak terlalu besar dibandingkan nilai impor yang dilakukan Indonesia selama 
kurun waktu penelitian. Sehingga bisa dikatakan bahwa tingkat ekspor netto suatu daerah berperan dalam meningkatkan pertumbuhan ekonomi regional walaupun belum begitu besar peranannya.

\section{KESIMPULAN}

Laju pertumbuhan angkatan kerja berpengaruh positif dan signifikan terhadap pertumbuhan ekonomi sehingga perlunya peningkatan kualitas angkatan kerja. Laju pertumbuhan penduduk berpengaruh negatif tapi tidak signifikan sehingga perlu adanya peningkatan kualitas penduduk dalam melakukan aktivitas ekonomi diimbangi dengan kuantitas penduduk. Laju pertumbuhan modal manusia berpengaruh positif tapi tidak signifikan terhadap pertumbuhan ekonomi maka perlu memperhatikan modal manusia merujuk pada penggunaan lag jumlah mahasiswa yang sedang menempuh studi di perguruan tinggi. Laju pertumbuhan inflasi berpengaruh negatif tapi tidak signifikan disebabkan antara lain karena inflasi berada pada tahap yang wajar sehingga tidak sampai menggerus pertumbuhan ekonomi tetapi pemerintah tetap perlu menjaga agar inflasi bisa terkendali. Laju pertumbuhan ekspor netto berpengaruh positif dan signifikan terhadap pertumbuhan ekonomi sehingga pemerintah harus dapat menjaga laju ekspor netto agar bisa terus surplus.

Kesimpulan di atas memiliki beberapa konsekuensi, pertama diperlukan adanya kualitas angkatan kerja yang unggul, terampil dan dapat diandalkan, yang diimbangi dengan kuantitas penduduk Indonesia; kedua, perlunya mempertimbangkan modal manusia merujuk pada penggunaan lag jumlah mahasiswa yang sedang menempuh studi di perguruan tinggi; ketiga, antisipasi terhadap laju inflasi dan pentingnya mempertahankan laju ekspor netto agar tetap surplus.

Penelitian ini memiliki beberapa keterbatasan antara lain periode waktu observasi yang relatif singkat (2006 - 2010). Kedua, akibat terbatasnya waktu periode, maka implementasi teori human capital dengan penggunaan lag jumlah mahasiswa dalam melihat produktivitas tamatan pendidikan, tidak dapat dilakukan. Hal initidak dimungkinkan mengingat asumsi masa tamat strata 1 adalah 4 tahun. 


\section{DAFTAR PUSTAKA}

Adi, Wijaya. 2011. Pengangguran. Wartawarga.gunadarma.ac.id diakses tanggal 4 Maret 2012

Bhinadi, Ardito. 2003. Disparitas Pertumbuhan Ekonomi Jawa dengan Luar Jawa. Jurnal Ekonomi Pembangunan Vol. 8, No 1, Juni 2003, Hal. $39-48$

Gama, Ayu Savitri. 2007. Disparitas dan Konvergensi Produk Domestik Regional Bruto Per Kapita Antar Kabupaten/Kota di Provinsi Bali. Jurnal Ekonomi dan Sosial, Vol. 2, No. 1

Hausman, Jerry. 2001. Mismeasured Variables in Econometric Analysis. The Journal of Economic Perspectives, Vol. 15, No. 4, pp $57-67$

Mankiw, Gregory. 2006. Makroekonomi Edisi keenam. Jakarta : Erlangga

McCombie, J.S.L and A.P. Thilwall. 1994. Economic Growth and the Balance-of-Payment Constraint. New York: St. Martin's

Ngangi, Charles. 2010. Social Capital in Alleviating Poverty. Jurnal Lasallian, Vol. 7, No. 2

Sendouw, Recky. 2006. Mengapa Indonesia Miskin?. www.hariankomentar.com diakses tanggal 6 Maret 2012

Simamora, Marganda dan Sirojuzilam. 2008. Determinan Pertumbuhan Ekonomi Regional Sumatera Utara. Jurnal Perencanaan dan Pengembangan Wilayah,Wahana Hijau Vol. 4 , No. 2, Desember 2008

Sodik, Jamzani, Didi Nuryadin dan Dedi Iskandar. 2007. Aglomerasi dan Pertumbuhan Ekonomi: Peran Karakteristik Regional. Parallel Session IVA, Urban and Regional, Fakultas Ekonomi UPN Veteran

Sodik, Jamzani dan Didi Nuryadin. 2005. Investasi dan Pertumbuhan Ekonomi Regional. Economic Journal of Emerging Markets. Vol. 10, No.2, Hal : 157 - 170

Sodik, Jamzani. 2006. Pertumbuhan Ekonomi Regional : Studi Kasus Analisis Konvergensi Antar Propinsi di Indonesia. Jurnal Ekonomi Pembangunan Vol. 11, No. 1, April 2006, Hal. $21-32$

2007. Pengeluaran Pemerintah dan Pertumbuhan Ekonomi Regional. Economic Journal of Emerging Markets. Vol. 12, No.1 
Sugiarto, Aris. 2011. Skripsi Analisis Pengaruh Pertumbuhan Kapital, tenaga kerja dan human capital terhadap pertumbuhan ekonomi di Indonesia. Universitas Pembangunan Nasional "Veteran"

Sukirno, Sadono. 2008. Teori Pengantar Makro Ekonomi. Jakarta : PT Raja Grafindo Persada Tjiptoherijanto, Prijono. 2001. Proyeksi Penduduk, Angkatan Kerja, Tenaga Kerja dan Peran Serikat Pekerja dalam Peningkatan Kesejahteraan. Majalah Perencanaan Pembangunan, Edisi 23

Todaro, Michael.P. dan Stephen C. Smith .2008. Pembangunan Ekonomi Edisi Ke Sembilan. Jakarta : Erlangga 